\title{
Labour Market Returns and Wage Inequality: New Evidence for Europe
}

\author{
Tiago Neves Sequeira ${ }^{1, *} \&$ Marcelo Santos ${ }^{1}$ \\ ${ }^{1}$ Dep. de Gestão e Economia, Universidade da Beira Interior and CEFAGE-UBI, Estrada do \\ Sineiro. 6200-209 Covilhã, Portugal \\ *Corresponding author: Dep. de Gestão e Economia, Universidade da Beira Interior and \\ CEFAGE-UBI, Estrada do Sineiro. 6200-209 Covilhã, Portugal. E-mail: sequeira@ubi.pt.
}

Received: July 16, 2015 Accepted: September 6, 2015 Published: September 28, 2015

doi:10.5296/rae.v7i3.8020 URL: http://dx.doi.org/10.5296/rae.v7i3.8020

\begin{abstract}
We study the relationship between returns to education and the wage distribution in Europe and we find evidence for a new fact: A hump-shaped relationship between returns and the wage distribution. This hump-shaped relationship between returns to education and the wage distribution means that investments on education contributes to increase inequality between the lower bound of the wage distribution and the median (roughly) but for the richer part of the wage distribution, education tends to decrease wage inequality. There is also evidence of a non-monotonous relationship between returns to tenure and gender, on one side, and the wage distribution, on the other side.
\end{abstract}

Keywords: Returns to Education, Mincer Regression, Wage Inequality.

JEL Codes: I21; J31; O52 


\section{Introduction}

We study the determinants of wages throughout Europe focusing on returns to education. The data used are from the European Working Conditions Survey (EWCS), 2005 wave, which allows us to compute estimations for all the covered European countries. Earlier work on the issue is quite abundant. There are several papers that dealt with the relationship between returns to education and the wage distribution. In particular, Machado and Mata (2001), Hartog et al. (2001) and Fersterer and Winter-Ebmer (2003) also used quantile regressions to estimate wage regressions and conclude that returns to education typically tend to be higher in the right tail of the distribution. However, most of previous work relied on specific country studies or on a small set of countries. Previous papers tend to use country-specific data. The use of EWCS data allow us to estimate regressions based on all the available European data.

In an article by Martins and Pereira (2004), for example, returns to education are higher for the right-hand tail of the wages distribution for most of the countries studied. A comparison between the first and ninth decile reveals that the only exception to that rule is Greece. However, some of the countries (Ireland, Germany and Spain) showed a slight decrease in the returns coefficient between the eighth and the ninth deciles. The fact that returns to education increase with income has important policy implications as it implies that education is in fact contributing to increase wage inequality. Martins and Pereira (2004) covered 15 European countries and the USA, based on a collection of country databases under the PuRE project. The country datasets were based on household surveys for eleven countries, labor-market survey and employer-based datasets for the remaining four. Our paper is based on a workers' survey throughout European countries, using a random sample of workers, thus relying on a more homogeneous international dataset, and using the same methodology throughout countries.

Other examples of papers predicting that returns to education increase as wages increase are Biagetti and Scicchitano (2011), based on data from the European Union Statistics on Income and Living Conditions inquiry (EU-SILC) - from 2005 and 2007, Behr and Pötter (2010), based on data from the European Household Community Panel (EHCP), dated from 2001. These papers cover much less European countries than we do.(Note 1) Despite using different databases, our method is similar to the first, but we use a more complete regression including more controls on individual and job characteristics, such as tenure, experience, age, gender, unemployment and marriage status, sectors, and firm size. Thus, using different data sources but also relying on a huge workers database and a standard methodology, the current paper contributes to the discussion on the relationship between returns to education and wage inequality, presenting a new result on the evolution of returns to education through the wage distribution.

In fact, we present evidence for a new stylized fact according to which returns of education increase for the left-hand part of the income distribution but decrease thereafter in Europe. This means that for the higher income earners, education may imply a decrease in wage inequality. 


\section{Data and Estimating Model}

We collected data from the 2005 wave of the European Working Conditions Survey (Note 2) (EWCS) (Eurofound, 2012) for 31 European countries: Belgium, Czech Republic, Denmark, Germany, Estonia, Greece, Spain, France, Ireland, Italy, Cyprus, Latvia, Lithuania, Luxembourg, Hungary, Malta, Netherlands, Austria, Poland, Portugal, Slovenia, Slovakia, Finland, Sweden, United Kingdom, Bulgaria, Croatia, Romania, Turkey, Norway and Switzerland. This survey was carried out under the supervision of the European Commission, and it aims to be an extension of the well-known survey from the European Community Household Panel (ECHP), which ended with the 2001 wave. This is one of the currently most complete databases on labor information for Europe.

This survey contains personal and labor market characteristics including wage, hours worked, gender, marriage status, experience, tenure, education levels and sector of the firm, among other variables. Education is measured by levels of education, the lowest being no-education (ISCED 0 - assumes value 1) and increases to primary education (ISCED 1 - value 2), lower secondary education (ISCED 2 - value 3), upper secondary education (ISCED 3 - value 4), post-secondary non-tertiary education (ISCED 4 - value 5), tertiary education, first level (ISCED 5 - value 6) and tertiary education, advanced level (ISCED 6 - value 7). As in Biagetti and Scicchitano (2011), we made a correspondence to years of schooling as follows: 0 years of schooling for ISCED 0, 6 years for ISCED 1, 8 years for ISCED 2, 11 years for ISCED 3, 14 years for ISCED 4, 18 years for ISCED 5 and 22 years for ISCED 6.

Additionally, the income-related variable in ECWS is Monthly income measured by deciles (divided into 10 parts, each part corresponding to a group of income of each country). EWCS describes its earnings variable as "giving the respondents a scale on which they can place themselves tends to produce higher response rates than enquiring directly about earnings. The problem facing international surveys, however, is how to make the scales meaningful in each country (by adapting them to the national pay levels) but also comparable internationally. The Foundation's approach to this issue in the fourth European Working Conditions Survey was to ensure that the national 10-point scales roughly matched the real distribution of earnings (and thus corrected for purchasing power parity). Using Eurostat's European Earnings Structure Survey 2002, the earnings of each EU country were divided into 10 bands (called 'deciles', each representing $10 \%$ of the respondents), and ranked from low to high." (Parent-Thirion et al., 2007). As assumed by the survey's authors, this methodology guarantees the comparability between income levels among different countries. For example, a person in the first decile in Austria can be compared with a person in the first decile in Greece. However, eventhough this variable has some interesting features, to be mostly consistent with previous contributions, we base on this available variable to construct a wages variable for our benchmark analysis. To this end, we use the table for the income bands for deciles available in the survey (the survey provides 9 limits for income bands) (Parent-Thirion et al., 2007: Table A.4, page 100). The survey provides bands in national currencies. We used Eurostat 2005 exchange rates to convert non-Euro national currencies on Euro.

Table 3.A. in the Appendix presents a description of the original variables used and the 
corresponding question on the survey.

We have estimated the following Mincerian earnings equation:

$$
w_{i}=\alpha_{0}+\alpha_{\theta 1} e d u_{i}+\alpha_{\theta 2} \exp _{i}+\alpha_{\theta 3} \exp _{i}^{2}+\alpha_{\theta 3} \operatorname{ten}_{i}+\boldsymbol{X}_{i}^{\prime} \theta
$$

where the subscript $\theta$ denotes the estimate at the $\theta$ th conditional quantile, in which $\theta=10,20$, $25,30,40,50,60,70,75,80$ and 90 . The dependent variable, $w_{i}$, is the log of net wage, $e d u_{i}$ is the education variable detailed above, $\exp _{i}$ is the experience variable (the number of years in paid employment), ten $_{i}$ is the tenure variable (number of years in the current employment in years) and $\boldsymbol{X}_{\boldsymbol{i}}$ is a vector of other explanatory variables, including age (and age squared), gender, an unemployment dummy, a marriage dummy, sector dummies, firm size dummies, and country dummies. (Note 3) Thus, $\alpha_{\theta 2}$ is our measure for returns to education and indicate the additional wage obtained by an additional year of schooling. Other coefficients measure the returns from different worker characteristics (experience, tenure, etc.). We based on diverse literature to support the inclusion of covariates in $\boldsymbol{X}_{\boldsymbol{i}}$. Originally, Mincerian equations include schooling variable as well as experience (see e.g. Heckman, Lochner and Todd, 2008). However, several contributions have intended to reduce unaccounted heterogeneity including several additional workers, employers and industry characteristics, such as tenure, gender, size of the firm and private-government ownership of the firm (e.g. Machado and Mata, 2001). The experience bias when other controls are not included may be linked with: (i) better matches associated with workers that have been longer in the labor market, (ii) high-ability workers are likely to have a stronger labour market attachment and hence end up with more experience; (iii) workers with higher returns to experience are likely to spend less time out of the labour market, because for them the opportunity cost of not working is higher (see Dustmann and Meghir, 2005). The typical solution to these potential biases on estimating the experience returns is to consider tenure and age as constant, i.e., include these variables in wage regressions as we do. Thus, additionally to education years, experience, experience squared and tenure detailed in equation (1), we also include in $\boldsymbol{X}_{\boldsymbol{i}}$ age and age squared. As robustness tests we consider the exclusion of age and age squared from the regression and also the inclusion of tenure squared. Our results are strongly robust to these specification changes, as we will detail below. Also, there is an extensive literature on the wage gender gap. A survey can be found in Kunze (2000). Thus, we also include a gender dummy in our regression (1 for male, 2 for female). Several previous works found a premium for married workers (see e.g. Chun, 2001 and Pollman-Schult, 2009). Thus we included a marriage dummy on our regression (1 for married or similar). Literature has also included the effect of unemployment on the wage profile (see e.g. Arulampalam, 2001) which led us to include an unemployment dummy (1 if unemployed). Finally, we also control for sector of activity of the firm and firm size (with one dummy for each sector and firm size category).

Contrary to previous articles on the issue, we implement baseline regressions for the whole Europe (for the whole database and not country by country). This explores the data comparability among the different country data in the database, attaining a much higher degree of freedom and generality of results than most of the previous articles. To account for 
country-specific effects, we include country-dummies in the regressions.

To assess the effect of different determinants of earnings, and specifically of returns to education throughout the wage distribution, and also following the most recent literature on the issue, we employ quantile regressions (Koenker and Hallock, 2001). Herein, we use the design matrix bootstrap method to obtain estimates of standard errors for the coefficients, with 100 interactions. This method is robust to relatively small samples and more importantly, it is valid under many forms of heterogeneity (Buchinsky, 1995, 1998).

The sample consists of 22748 observations. Number of observations for each country is detailed in Table 1.A. in the Appendix. When creating the wages variable we loss some of the observations due to the fact that for 10 deciles, the survey only provide 9 values for the income bands. This results in 20107 observations.

\section{Results}

This section presents the results of our regressions. First, we describe the results of the regression specified in (1). Second, we also present the results from a regression that used an alternative dependent variable for wage. In our case, the alternative dependent variable is indeed the source EWCS variable for income, which is a variable in a scale 1 to 10 , also described above. Despite this approach is quite original in the empirical literature that precedes this paper, we recognize that this variable has the advantage of being robust to differences in purchase power between countries, controlling better for country-specific differences. We present the main results using graphics that show the coefficients of the different covariates for the different estimated quantiles, as well as confidence intervals for each of the variables coefficients. (Note 4)

As can be observed in Figure 1, returns to education are around 2\% in the lowest decile, reaches $3.6 \%$ around the median wage and again drops to near $3 \%$ in the $9^{\text {th }}$ decile. As may be concluded by the tight confidence interval, the precision of estimates is quite high and the significance level is near $0 \%$. While is obvious that the return to school is increasing until the $7^{\text {th }}$ decile of the wage distribution increasing nearly $1.6 \%$ in this first part of the wage distribution, it is also significant that it then begins to decrease with a drop of nearly $0.6 \%$, meaning that a given increase in education years contributes to increase inequality until the $7^{\text {th }}$ decile and then contributes to decrease inequality for the highest deciles. It is also interesting that returns to tenure have a similar profile although with a much lower return that oscillates between $0.4 \%$ and $0.6 \%$ per additional year of tenure. Experience and Age have also statistically positive significant coefficients while experience squared and age squared present negative and statistically significant coefficients. Being a female implies a statistically significant wage penalty which oscillates between nearly $15 \%$ to nearly $19 \%$ in a profile that resembles a U-shaped relationship. Being married represents a wage premium between nearly $0.5 \%$ to nearly $2.6 \%$ with an increasing pattern throughout the wage distribution and being unemployed represents a penalty of more than $10 \%$. These signs and quantitative effects have strong support in the literature. As noted before, the great novelty on these results is the 
hump-shaped relationship between returns to education and the wage distribution.
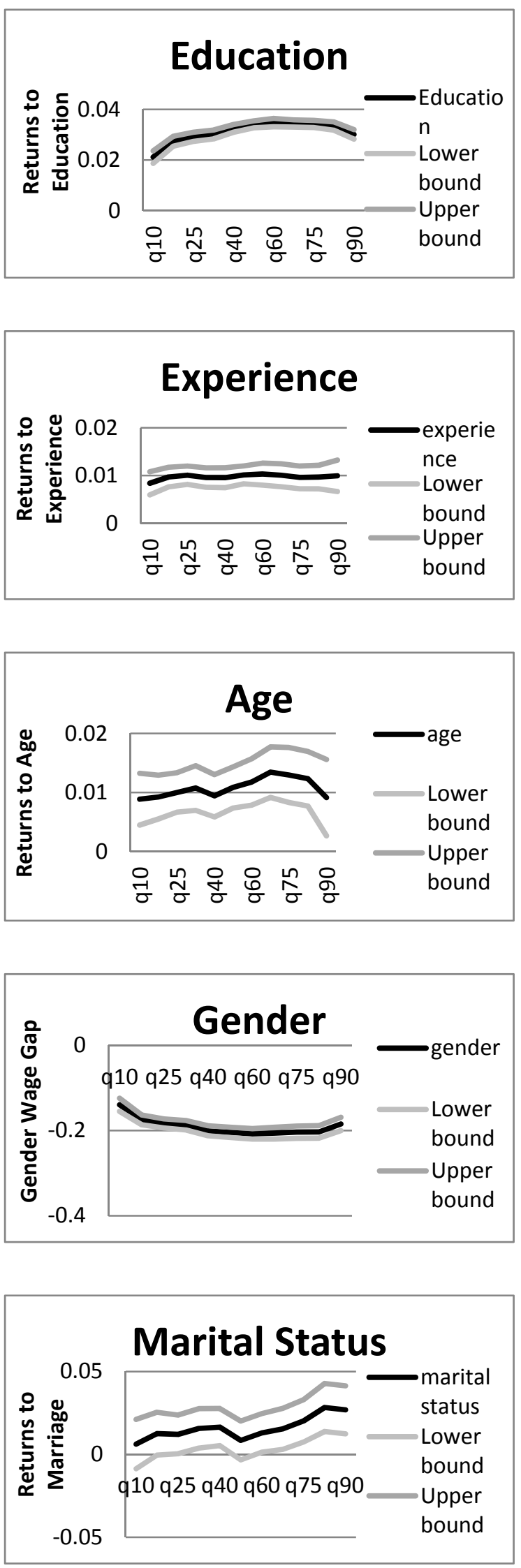
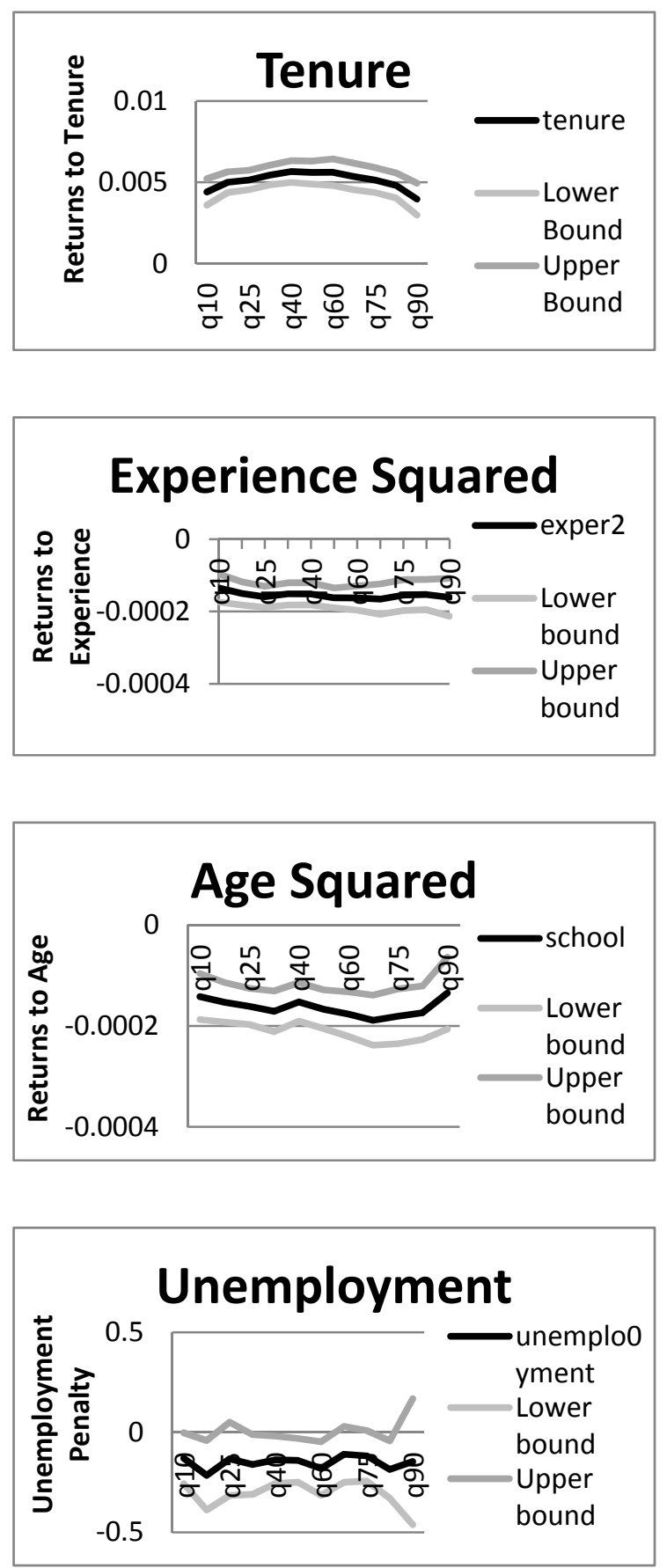

Figure 1. Coefficients and confidence intervals for the different determinants of wages in equation (1). Number of observations: $20107 . \mathrm{R}^{2}$ oscillate between 0.647 and 0.727 . 

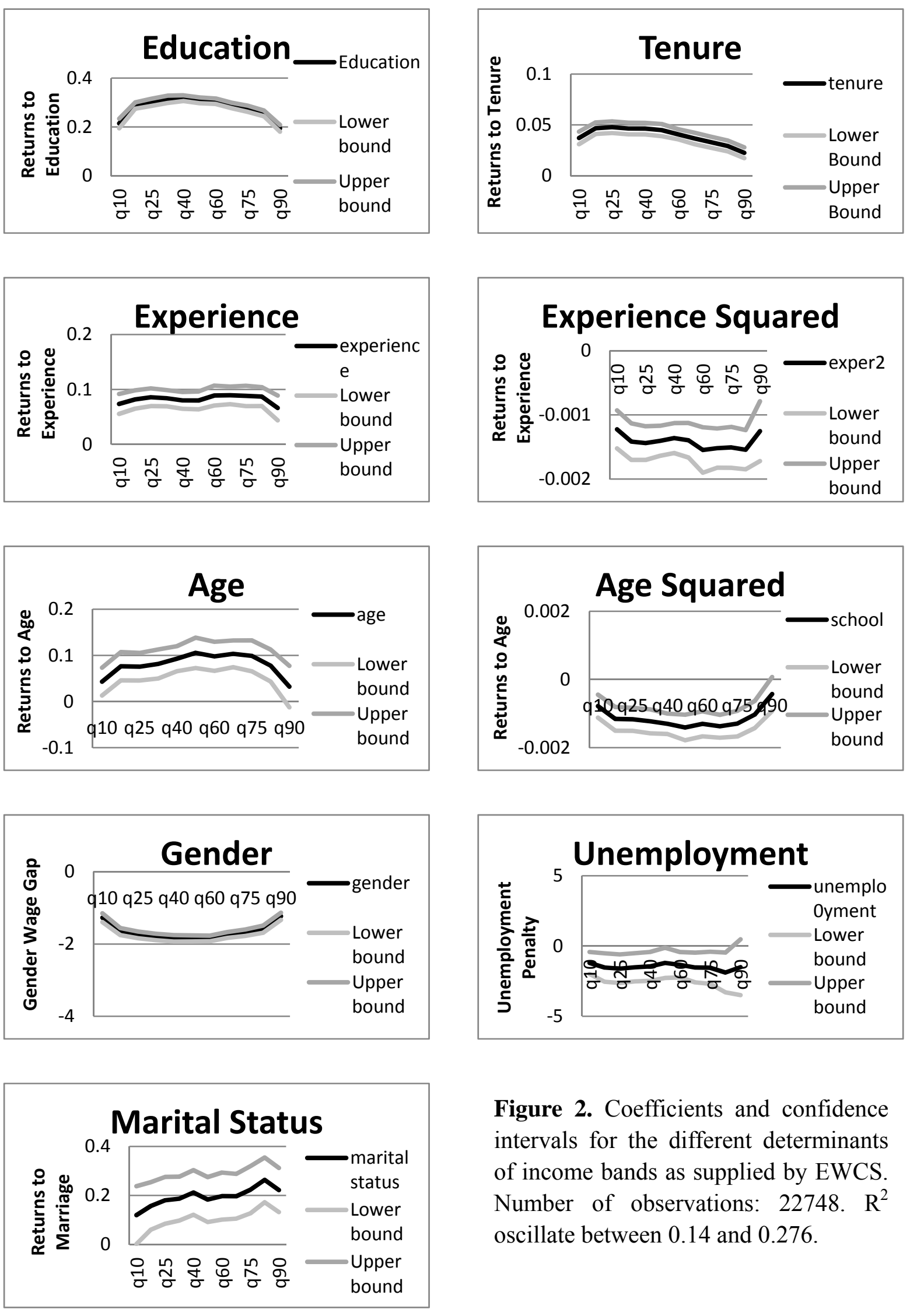

Figure 2. Coefficients and confidence intervals for the different determinants of income bands as supplied by EWCS. Number of observations: 22748. $\mathrm{R}^{2}$ oscillate between 0.14 and 0.276 . 
Despite the change in the dependent variable, Figure 2 shows that the qualitative effects of the determinants of wages are strikingly similar. The hump-shaped relationship between returns to education and the wage distribution is even more evident than in Figure 1. Now, the effect of school on wages reaches a maximum in the $4^{\text {th }}$ decile, above which a given increase in schooling begins to contribute to decrease wage inequality. The quantitative effects now oscillate between near $20 \%$ (in the $1^{\text {st }}$ and in the $9^{\text {th }}$ decile) and $32 \%$ in the $4^{\text {th }}$ and $5^{\text {th }}$ decile. This means that an additional year of school contributes in average to an increase of $1 / 5$ of an income decile to roughly $1 / 3$ of an income decile. The precision of the school coefficients is again very high across the income distribution. Despite the expected differences in quantitative effects, other coefficients have quite similar patterns and precision compared to what we found in Figure 1. Tenure, for instance, also presents a hump-shaped relationship with the distribution of income and Gender presents a U-shaped relationship with the income distribution. As before, results indicate a female wage penalty.

Next, we will present the results of interquantile significance tests to evaluate quantitatively if the differences in coefficients between deciles are statistically significant. Table 1 shows the results of the difference in coefficients tests between the $5^{\text {th }}$ and the $1^{\text {st }}$ decile and also between the $9^{\text {th }}$ and the $5^{\text {th }}$ decile. Thus we expect to find a significantly positive difference between the $5^{\text {th }}$ and the $1^{\text {st }}$ decile and a significantly negative difference between the $9^{\text {th }}$ and the $5^{\text {th }}$ decile.

Table 1. Inter-decile Tests

\begin{tabular}{lllll}
\hline Dependent Variable & \multicolumn{2}{c}{ Log(wage) } & \multicolumn{2}{c}{ Income (EWCS) } \\
\hline Explanatory & 5 th-1st & 9th-5th & 5th-1st & 9th-5th \\
Variable & deciles & deciles & deciles & deciles \\
Edu & $0.013^{* * *}$ & $-0.004^{* * *}$ & $0.095^{* * *}$ & $-0.115^{* * *}$ \\
Exp & 0.002 & -0.000 & 0.006 & -0.014 \\
Exp & -0.00 & 0.000 & 0.000 & 0.000 \\
Ten & $0.001 * *$ & $-0.002^{* * *}$ & $0.008^{* *}$ & $-0.022^{* * *}$ \\
Gender & $-0.065^{* * *}$ & $0.020^{* *}$ & $-0.572^{* * *}$ & $0.614^{* * *}$ \\
Age & 0.002 & -0.002 & $0.062^{* * *}$ & $-0.073^{* * *}$ \\
Age & -0.00 & 0.000 & $-0.001 * * *$ & $0.001 * * *$ \\
Marital & 0.00 & $0.018^{* *}$ & 0.063 & 0.039 \\
Unemp & -0.01 & -0.006 & 0.005 & -0.308 \\
\hline
\end{tabular}

Notes: * indicates that the deciles coefficients are significantly different at $10 \%$ level of significance; ** indicates that the deciles coefficients are significantly different at $5 \%$ level of significance; *** indicates that the deciles coefficients are significantly different at $1 \%$ level of significance.

First row in Table 1 indicates that our main finding, the hump-shaped relationship between returns to education and the wage distribution is in fact statistically significant with high level of significance (always at much less than the 1\% level). (Note 5) In fact, the table shows that there are significantly positive differences between the coefficient on the median and the coefficient on the $1^{\text {st }}$ decile and there are significantly negative differences between the 
coefficient on the $9^{\text {th }}$ decile and the coefficient on the median. This is valid both for our net wage variable as well as for the original income variable from EWCS. Interestingly the similar pattern of Tenure and the 'inverted' pattern for Gender we have also found above are also statistically significant. In general, coefficients on other covariates are not statistically different between the top distribution and the median and between the median and the bottom distribution. There are only few exceptions. First, the marital premium seems to significantly increase on the second half of the distribution for the regressions in which the dependent variable is the log of wage. Second, the non-linear effect of age on income (as defined by the EWCS) seems also to significantly differ between the tested points of the distribution.

We perform a number of specification tests that we used to test the robustness of our results. First, we have run original Mincerian regressions, in which we only included the edu variable, experience and experience squared and country dummies. In this case, the hump-shaped relationship would be even stronger. In fact, considering wage regressions, the increase in returns to education in the lower side of the distribution would be steeper, attaining a maximum of $3.6 \%$ in the median (contrary to what happened in the benchmark regression, in which the maximum happened at the $7^{\text {th }}$ decile). The drop in the returns to education after the median would also be steeper. The minimum return is obtained for the $1^{\text {st }}$ decile $(1.7 \%)$ with the second lowest value being obtained in the $9^{\text {th }}$ decile $(2.3 \%)$. When the EWCS income variable is used instead of wages, the maximum return to school would be obtained in the $3^{\text {rd }}$ decile. Thus, the evidence of a significant decrease of the return to education is obtained for a greater (right-hand) part of the distribution of wages when we consider a simpler Mincerian specification, often used in the literature. Second, we performed regressions in which we excluded age and age squared. In this case, results do not change much from those obtained in the benchmark specification. Returns to education range from $2.1 \%$ (in the $1^{\text {st }}$ decile) to a maximum of $3.48 \%$ (on the $6^{\text {th }}$ decile) and then to $2.99 \%$ (in the $9^{\text {th }}$ decile). Third, we include also tenure squared in the regression. In this case, the pattern obtained would be similar to that obtained with the last specification test. In fact, returns to education range from $2.1 \%$ (in the $1^{\text {st }}$ decile) to a maximum of $3.44 \%$ (on the $6^{\text {th }}$ decile) and then to $3.01 \%$ (in the $9^{\text {th }}$ decile). (Note 6 )

According to Martins and Pereira (2004), there are three possible reasons for obtaining a positive relationship between returns of education and wages quantiles: overeducation in low paid jobs may lead to quite low returns to education in the left-hand tail of the distribution; ability, which is thought to be increasing with the wage distribution and can amplify the returns of schooling in the right-hand tail of the distribution; heterogeneity of school-quality or fields of study, which means that the bottom of the wage distribution may have low-schooling-quality individuals or individuals from less demanded fields of study over-represented. Our hump-shaped relationship implies that these explanations cannot be valid for all of the wage distribution and namely for its right-hand tail. A candidate explanation in this case might be that schooling-quality suffers from decreasing returns to scale so as in high wage individuals further increases in school quality has not additional effect and in fact we might find some highly paid workers which have been endowed with poor-quality schooling. Thus, in the right-hand tail of the distribution there is an over-representation of high-ability, high-tenured, and highly-experienced workers which may present relatively lower 
returns to education. (Note 7) This candidate explanation should be seen just as tentative as a complete explanation is beyond the scope of this paper.

\section{Conclusions}

In this paper we present evidence according to which returns to education are positively related to wages in the left-hand tail of the wage distribution but tend to be negatively related to wages in the right-hand tail of the wage distribution. This new pattern arising between returns to education and the wage distribution may constitute a challenge to new empirical research that can confirm it and to new theoretical research which may explain it.

Our results also show that this schooling returns pattern is quite precise, from the statistical point of view. Additionally, it is robust to several specification changes to the estimating equation. We have also shown a significant hump-shaped relationship between tenure and the wage distribution - somewhat less precise than the pattern found for wages, yet with high statistical significance. Moreover, we found a U-shaped relationship between the gender variable (the female wage penalty) and the wage distribution. Other determinants of wage did not present significant differences throughout the wage distribution.

The main finding in this paper has relevant policy implications. If a push for education seems to decrease wage inequality when comparing those on the median income with those on the top of the distribution, this means that subsidizing education of the median class would have an effect of decreasing inequality (comparing the wage of the median class with the richer). This is an opposite prediction when compared to that one could obtain from previous evidence. In fact, based on an always increasing return throughout the income distribution, overall education subsidies would always contribute to increase inequality as returns of the richer would be always higher than the ones of the poorer.

\section{Acknowledgement}

We acknowledge financial support from Fundação para a Ciência e Tecnologia through project PTDC/EGE-ECO/112499/2009. We are grateful to comments and suggestions from Alexandra Ferreira-Lopes and Paulo Maçãs Nunes.

\section{References}

Arias, O., Hallock, K., \& Sosa-Escudero, W. (2001). Individual heterogeneity in the returns to schooling: instrumental variables quantile regression using twins data. Studies in Empirical Economics, 26, 7-40. http://dx.doi.org/10.1007/s001810000053

Arulampalam, W. (2001). Is unemployment really scarring? Effects of unemployment experiences on wages. Economic Journal, 111(475), 585-606. http://dx.doi.org/10.1111/1468-0297.00664 
Badesco, M., B. D’Hombres \& E. Villalba. (2011). Returns to Education in European Countries: evidence from the European Community Statistics on Income and Living Conditions (EU-SILC), JRC Scientific and Technical Reports EUR 24850 EN- 2011. http://dx.doi.org/10.2788/31157

Behr, A., \& Potter, U. (2010). What determines wage differentials across the EU? Journal of Economic Inequality, 8(1), 101-120. http://dx.doi.org/10.1007/s10888-008-9106-z

Biagetti, M., \& Scicchitano, S. (2011). Education and wage inequality in Europe. Economics Bulletin, 31(3), 2620-2628.

Buchinsky, M. (1995). Estimating the asymptotic covariance matrix for quantile regression models: a Monte Carlo study. Journal of Econometrics, 65, 109-54. http://dx.doi.org/10.1016/0304-4076(94)01652-G

Buchinsky, M. (1998). Recent advances of quantile regression: a practical guideline for empirical research. Journal of Human Resources, XXXIII, 88-126. http://dx.doi.org/10.2307/146316

Chun, H. L. (2001). Why Do Married Men Earn More: Productivity or Marriage Selection? $\begin{array}{lll}\text { Economic Inquiry, 39(2001), } & \text { 307-319. }\end{array}$ http://dx.doi.org/10.1111/j.1465-7295.2001.tb00068.x

Dustmann, C., \& Meghir, C. (2005). Wages, Experience and Seniority. Review of Economic Studies ,72, 77-108. http://dx.doi.org/10.1111/0034-6527.00325

Eurofound. (2012). Trends in job quality in Europe, Publications Office of the European Union, Luxembourg.

Fersterer, J., \& Winter-Ebmer, R. (2003). Are Austrian returns to education falling over time? Labour Economics, 10, 73-89. http://dx.doi.org/10.1016/S0927-5371(02)00105-7

Hartog, J., Pereira, P., \& Vieira, J. (2001). Changing returns to education in Portugal during the 1980s and early 1990s: OLS and quantile regression estimators. Applied Economics, 33, 1021-1037. http://dx.doi.org/10.1080/00036840122679

Heckman, J., Lochner, L., \& Todd, P. (2008). Earnings Functions and Rates of Return, Working-Paper 13780, NBER - National Bureau of Economic Research. http://dx.doi.org/10.3386/w13780

Koenker, R., \& Hallock, K. (2001). Quantile regression: an introduction. Journal of Economic Perspectives, 15, 143-56.

Kunze. A. (2000). The Determination of Wages and the Wage Gender Gap: a Survey, IZA DP 193, August.

Machado, J., \& Mata, K. (2001). Earnings functions in Portugal 1982-1994: evidence from quantile regressions. Empirical Economics, 26, 115-134. http://dx.doi.org/10.1007/s001810000049 
Martins, P., \& Pereira, P. (2004). Does Education reduce wage inequality? Quantile evidence from 16 countries. Labour Economics, 11, 355-371. http://dx.doi.org/10.1016/j.labeco.2003.05.003

Parent-Thirion, A., Fernández Macías, E., Hurley, J., \& Vermeylen, G. (2007). Fourth European Working Conditions Survey, Dublin.

Pollman-Schult, M. (2011). Marriage and Earnings: Why Do Married Men Earn More than Single Men? European Sociological Review, 27(2), 147-163. http://dx.doi.org/10.1093/esr/jcp065

\section{Notes}

Note 1. Biagetti and Scicchitano (2011) estimate regressions for Austria, Belgium, Spain, Greece, Ireland, Italy, Poland, and Portugal. Behr and Pötter (2010) include in the analysis the following countries: UK, Germany, Denmark, Belgium, France, Ireland, Italy, Greece, Spain, and Portugal. An European Commission report from Badescu et. al. (2011) which is also based on data coming from EU-SILC (2005 wave) present OLS regression (with no implication for the wage distributional effects of returns to education) for 24 countries.

Note 2. http://eurofound.europa.eu/ewco/surveys/

Note 3. We assume that workers' attributes determining the wages are exogenous variables. This follows most of the literature such as Martins and Pereira (2004), Machado and Mata (2001), Hartog et al. (2001), Fersterer and Winter-Ebmer (2003) and Biagetti and Scicchitano (2011). An IV approach to quantile regressions is possible when twin data are available, which is not the case here. Nevertheless, Arias et al. (2001) showed that the differences in coefficients between non-IV and IV estimates are non-significant.

Note 4. We include a table - Table 2.A - with coefficients for returns to education throughout different quantiles in the Appendix. Coefficients for other covariates are available upon request.

Note 5 . The p-values on those differences are always less than 0.001 .

Note 6 . Results of these robustness tests are available upon request.

Note 7. In fact, correlations between tenure and income and experience and income are positive and statistically significant, which indicate that more tenured and experienced workers are more represented in higher quantiles of wages. 


\section{APPENDIX}

Table 1.A: Number of observations for each country and total

\begin{tabular}{llllllll}
\hline Country & $\begin{array}{l}\text { N. } \\
\text { Obs }\end{array}$ & Country & $\begin{array}{l}\text { N. } \\
\text { Obs }\end{array}$ & Country & $\begin{array}{l}\text { N. } \\
\text { Obs }\end{array}$ & Country & $\begin{array}{l}\text { N. } \\
\text { Obs }\end{array}$ \\
\hline & & Spain(8) & 695 & Luxembourg(16) & 468 & Slovakia(24) & 814 \\
Austria(1) & 610 & Finland(9) & 955 & Latvia(17) & 796 & UK(25) & 626 \\
Belgium(2) & 687 & France(10) & 703 & Netherlands(18) & 823 & Norway(26) & 848 \\
Cyprus(3) & 551 & Greece(11) & 801 & Malta(19) & 488 & Switzerland(27) & 889 \\
Czech Rep.(4) & 659 & Hungary(12) & 846 & Poland(20) & 706 & Bulgaria(28) & 877 \\
Germany(5) & 839 & Ireland(13) & 797 & Portugal(21) & 747 & Croatia(29) & 639 \\
Denmark(6) & 924 & Italy(14) & 658 & Sweden(22) & 994 & Romania(30) & 702 \\
Estonia(7) & 446 & Lithuania(15) & 801 & Slovenia(23) & 469 & Turkey(31) & 890 \\
Total & 22748 & & & & & & \\
\hline
\end{tabular}

N. Obs stands for Number of Observations.

Table 2.A: Coefficients for returns to schooling and its significance

\begin{tabular}{lllllll}
\hline $\begin{array}{l}\text { Dep. } \\
\text { Variable: }\end{array}$ & \multicolumn{1}{c}{$\begin{array}{l}\text { log (wage) } \\
\text { Coefficient }\end{array}$} & Standard-Error & p-value & Coefficient & Standard-Error & p-value \\
& 0.0211255 & 0.0012577 & 0.000 & 0.2142394 & 0.0100005 & 0.000 \\
q10 & 0.0274087 & 0.0009883 & 0.000 & 0.2875323 & 0.0065744 & 0.000 \\
q20 & 0.0291498 & 0.0009154 & 0.000 & 0.300838 & 0.0075019 & 0.000 \\
q25 & 0.0300755 & 0.0008966 & 0.000 & 0.3127903 & 0.0076023 & 0.000 \\
q30 & 0.0325161 & 0.0007774 & 0.000 & 0.3176301 & 0.0059523 & 0.000 \\
q40 & 0.034062 & 0.0006973 & 0.000 & 0.3090049 & 0.0060862 & 0.000 \\
q50 & 0.0347715 & 0.000842 & 0.000 & 0.305153 & 0.0057834 & 0.000 \\
q60 & 0.0344182 & 0.0007336 & 0.000 & 0.2877507 & 0.0057931 & 0.000 \\
q70 & 0.034188 & 0.0007181 & 0.000 & 0.2742142 & 0.0064896 & 0.000 \\
q75 & 0.0334038 & 0.0008293 & 0.000 & 0.255508 & 0.0060242 & 0.000 \\
q80 & 0.0301303 & 0.0009596 & 0.000 & 0.1943856 & 0.0071679 & 0.000 \\
q90 & & & & & & \\
\hline
\end{tabular}




\section{MlMacrothink}

Table 3.A. Variables and their measures

\begin{tabular}{|c|c|c|c|}
\hline $\begin{array}{l}\text { Variable } \\
\text { Code }\end{array}$ & Variable Name & $\begin{array}{l}\text { Name used at } \\
\text { the regression }\end{array}$ & Measure \\
\hline ef5 & Income & Income/wage & $\begin{array}{l}\text { Monthly income measured by deciles (divided by } 10 \text { parts, each } \\
\text { part corresponds to a group of income of each country) } \\
\text { ["01" A; "02" B; "03" C; "04" D; "05" E; "06" F; "07" G; "08" H; } \\
\text { "09" I; "10" J] } \\
\text { Converted in wages using decile bands provided in the survey. }\end{array}$ \\
\hline ef1 & $\begin{array}{l}\text { Education } \\
\text { Level }\end{array}$ & edu & $\begin{array}{l}\text { Measures the highest level of education that respondent } \\
\text { successfully completed [for most countries it is: "1" No education; } \\
\text { "2" Primary education; "3" Lower secondary education; "4" Upper } \\
\text { secondary education; "5" Post-secondary including pre-vocational } \\
\text { or vocational } \\
\text { education but not tertiary; "6" Tertiary education - first level; "7" } \\
\text { Tertiary education - advanced level] } \\
\text { Converted in education years using the rule explained in the text. }\end{array}$ \\
\hline $\mathrm{q} 2 \mathrm{~d}$ & $\begin{array}{l}\text { Years in } \\
\text { Company }\end{array}$ & ten & $\begin{array}{l}\text { Number of years that respondent is working at the company [" } 00 " \text { if } \\
\text { less than } 1 \text { year; number of years] }\end{array}$ \\
\hline q2c & Working Years & exper & $\begin{array}{l}\text { Number of years that respondent stopped full-time education and } \\
\text { started a paid employment }\end{array}$ \\
\hline hh3b & Age & age & Number of years of the respondent \\
\hline hh2a & Gender & gender & Gender of Respondent ["1" for male; "2" for female] \\
\hline $\begin{array}{l}\text { From } \\
\text { hh2d }\end{array}$ & Unemployment & unemp & $\begin{array}{l}\text { Dummy created for unemployed (" } 1 \text { " for unemployed; " } 0 \text { " } \\
\text { employed). Original variable: Employment }\end{array}$ \\
\hline q5 & $\begin{array}{l}\text { Company } \\
\text { Sector }\end{array}$ & companysector & $\begin{array}{l}\text { Dummies created for private sector; public sector; joint } \\
\text { private-public organization or company; } \\
\text { and non-for-profit sector. Original variable: Sector that } \\
\text { respondent works ["1" private sector; " } 2 \text { " public sector; "3" joint } \\
\text { private-public organization or company; } \\
\text { "4" non-for-profit sector, NGO; "5" other] }\end{array}$ \\
\hline q6 & Company Size & companysize & $\begin{array}{l}8 \text { dummies created for different company sizes. Original variable; } \\
\text { Company size which is measured by number of employees that } \\
\text { respondent's workplace has [" } 01 \text { " for } 1 \text { (interviewee works alone); } \\
\text { " } 02 \text { " for } 2-4 \text {; " } 03 \text { " for } 5-9 \text {; " } 04 \text { " for } 10-49 \text {; " } 05 \text { " for } 50-99 \text {; " } 06 \text { " } \\
100-249 \text {; " } 07 \text { " for } 250-499 \text {; " } 08 \text { " for } 500 \text { and over] }\end{array}$ \\
\hline
\end{tabular}

Notes: 'No opinion' and, 'refuses to answers' cases were eliminated from the database, as well as the case of still a full-time student in variable q2c. 


\section{Copyright Disclaimer}

Copyright for this article is retained by the author(s), with first publication rights granted to the journal.

This is an open-access article distributed under the terms and conditions of the Creative Commons Attribution license (http://creativecommons.org/licenses/by/3.0/). 